\title{
Correction to: The Palgrave Handbook of EU Crises
}

\author{
Marianne Riddervold, Jarle Trondal, and Akasemi Newsome
}

\section{Correction to:}

M. Riddervold et al. (eds.), The Palgrave Handbook of EU Crises, Palgrave Studies in European Union Politics, https://doi.org/10.1007/978-3-030-51791-5

In the original version of this book, in the list of contributors, the affiliation for "Hubert Zimmermann" which was incorrectly included as "Gutenberg University in Mainz" instead of "Philipps University of Marburg (Germany)" has now been corrected. Also, in Chapter 16, the author name H. Kassim which was mistakenly added twice has been removed and the disclaimer for Luc Tholoniat has been added. The corrections to the book have been updated with the changes.

The updated version of the book can be found at https://doi.org/10.1007/9783-030-51791-5 